Akarçay Ulutaş, D. (2018). A Brief Discussion on Social Work Ethics Education. Journal of Academic Perspective on Social Studies, (1), 11-19.

\title{
A BRIEF DISCUSSION ON SOCIAL WORK ETHICS EDUCATION
}

\begin{abstract}
Ethics has become a crucial evaluation criterion in various sciences as well as social work in recent years. Ethical perspectives present complex needs and worlds, which people can mention about sociocultural difference. Following the right way while solving and discussing on ethical issues can open a new window in an individual's life, as well as, this relative approach should be reflected as to professional standards to the students in social work. It is obvious to aware the role of social work in human life as supporting social justice, advocacy, enhancing welfare.

The aim of social work is to support individuals as allowing self- determination and the right to direct life in what way they desire. Therefore, social work and social work ethics education have responsibilities to protect rights and areas of freedom of the clients. This perspective has indicated the objective of this paper as discussing the effects of multicultural perspectives, legal regulations, technological developments on ethics course in social work program briefly.
\end{abstract}

Keywords: Ethics, Ethics Education, Social Work Education

\section{INTRODUCTION}

Ethics, which is an important part of social work education, reflects and determines the effectiveness of social work practice and the relationship between social workers and clients. Social work ethics education has become a remarkable issue all over the world considering as both license qualification of the profession and changing individuals' lives and societies' structures. Social work education has an authentic model shaped with both theoretical background and practice. While this model has a complexity of dilemma with theory and practice, course contents should be framed as to standards and evaluated measurable outcomes (Alptekin, 2016). Social work ethics is one of these courses, which has a crucial place in balance between social work education and practice. Ethical codes and values in social work occupy a unique course in social work educational process and these issues are also taught in other course contents. In both contents, social work

\footnotetext{
${ }^{1}$ KTO Karatay University, Turkey, demetakarcay@gmail.com, ORCID ID: https://orcid.org/0000-0001-5872-2549
} 
instructor follows universal standards of ethical values and has an effort to adapt universal values and perspectives into local values by considering on ethical dilemmas. This framework presents a triangle of social work ethics education as ethical standards, supervision that forges a professional link between instructor and student and developing skills about finding solutions for ethical dilemmas.

A demanding challenge for social workers may occur as referring to obtain ethical outcomes and measure the ethical issues and solution in social work practice. In the point of all this, social welfare and individual well- being can be a reference for measurement and evaluation of social work practice in terms of ethical standards. Reid and Billups (1986, p. 6) study on ethical perspective of the outcomes of social work intervention shaping with the rearrangement of the balance between needs of individuals, families and communities and resources such as money, services, power and status. In this relational process and intervention, social work as a profession has core standards and models to prevent or copy with problems generated by different perspectives or characteristics. Social work education has a theoretical background about ethical principles and responsibilities in profession. However, the difference between understanding and practice is confronted as a depth discussion (Biggerstaff, 2005, p. 246).Ethical standards and anti-oppressive approach light the ways of professional training, practices and policies (Mulé, 2006, p. 608).Besides, the core of ethics and standards have a critical role to designate boundaries in the professional relationship and provide leastwise an origin to obtain outcomes of social work intervention.

Collective consciousness is the most appropriate concept to relay the effect of cultural background and social environment on behaviors, thoughts, values and beliefs. Since the reality of interaction between individuals is valid and the same for all communities, social worker must accept the unique of client and aware individuality. This framework can be summarized as that the social work ethics focus on value, morality of client and ethical behavior of the practitioner (Congress, 2002, p. 152).In the light of all this paradigmatic analysis, this paper discusses social work ethics education in terms of ethical responsibility to clients and society. In this view, informed consent, anti- oppression as an ethical perspective and confidentiality have evaluated as a part of ethical commitment to clients. These values and responsibilities preferred because of considering as the most handled discussion topics by the students during the course social work ethics in Turkey. 


\section{ETHICAL VALUES IN SOCIAL WORK EDUCATION}

Although ethical values have not reflected a new discussion topic in science, these have enhanced within years through the changing perspectives of people in the context of variable patterns of needs and thoughts. Reamer (1998) expresses the evolution in social work ethics education as the morality period, the values period, the ethical theory and decision-making period and the ethical standards and risk management period. Accordingly, ethical standards and responsibilities have transformed from preoccupation as client's morality and values to ethical guidelines for social work practices over years (Reamer, 1998, p. 488). Bryan (2006, p. 3) emphasizes actual central point of social work ethics education within two main aims as "exposure to the professionally specific principles important to the field of study, which indicate what one ought to do in this role" and "cultivation of ethical decision-making capabilities in the face of ethical problems, which requires that, at the least, one consider what one ought not do". Many skills of social worker such as problem-solving skills based on ethical dilemmas, effective communication, analytic thinking have handled in dual relationship through social work practice.

While obtaining information about individual values and needs, ethical standards of social work are required as well as individual understanding and meaning about the problem and need. "Core values" of the profession, which are highlighted by National Association of Social Workers' Code of Ethics (1999), lead social workers to manage ethical decisionmaking process and transform individual value and moral acts to professional case management. Besides, these "core values" of social work has a role as a guide (Bryan, 2006, p. 2)to identify the states of social worker and client in the context with the affected and affecting relations of social environment of client such as family, friends, groups, society. Six main codes of ethics in the framework with social work practice are aligned as responsibilities to clients, colleagues, in practice settings, as professionals, to the social work profession and society (Congress, 2002, p. 153). Although these core values are reflected to social work education with course of ethics, professional life and practices may present various aspects for disjuncture occurred discrepancy between belief and behavior. DiFranks (2008, p. 167)states this schema as describing the effects of different work settings on disjunction with the highest scores among social workers working at public agencies. Moreover, the study results that lower discordance of belief and behavior among social workers, who took social work ethics course, indicate the importance of ethics education. From this point of view, academicians in social work department should strike 
the right balance between theory and practice. Practice training for social work students should be accepted as life- sustaining part of social work education. Academicians must also address the social work theory with the practical background and sample cases to describe ethical perspective, decision making and the possible ways of creating solutions to ethical dilemmas.

In recent years, core ethical values of social work incline to cover all situations, problems, needs, perspectives and beliefs. Equality and respect for all differences can be admitted as the building blocks within the social work practice and ethical decision making process. Reamer (2013, p. 24) underlines core social work values of NASW Standards for the Classification of Social Work Practice as formulating the triangle of social work practice, education and developing skills in social work intervention. According to this classification, basic values of profession include;

- Awareness of otherness of the individual in society

- Respecting the confidentiality of relationships with clients,

- Intending to create social change by meeting needs,

- Being able to separate personal feelings and needs from professional intervention,

- Awareness of differences

- Supporting clients' skills to help themselves by developing their resilience and coping strategies,

- Strengthening clients despite their frustrations,

- Tracing social justice and making effort to nourish the economic, physical and mental well -being of all members of society,

- Awareness of high standards of personal and professional conduct.

The core principles of social work education refer to social justice, human value and relationships, advocacy and integrity, fidelity and competence as constructing social work model. The concept of social justice can be questioned within supporting client access to resources, opportunities, social goods and participation in life effectively. Human value and relationships can be evaluated in terms of strengthening and improving interdependent autonomy, functionality and promoting self- determination. While helping people in need as to social rights, prevention harm to others and individuals and unethical practices by others emphasizes advocacy and integrity, fidelity and competence refer to practices of social worker by keeping promises, having supervision in the light of laws, legal regulations and ethical standards (Pugh, 2017, p. 319). All these concepts and standards constitute the main template of social work ethics education. 
People may ponder on how the students can eliminate individual ethical perspectives while social work practice and when they can violate the boundaries of ethical values by separating cultural background and social interaction from social work theory or how they can consider them all together while trying to build the conformity with the clients. At this juncture, the objectives of social work ethics education, which have been classified by Reamer (2001, pp. 20-21) as stimulating moral imagination, developing analytic skills, eliciting a sense of moral obligation and personal responsibility and develop the ability to respond to ethical controversy and ambiguity (Hugman, 2005, p. 541), can teach the students their position in the professional interaction with clients. Dodd and Jansson (2004, pp. 457-459) enhance social work ethics education from traditional model to an expanding new model within five steps. In traditional model, first step begins with values in social work and ethical reasoning. Second step continues with discussing ethical issues in the shape of professional environment. In the third step, NASW codes of ethics are discussed. Moreover, discussing strategies for ethical deliberation is suggested as fourth step and model for theoretical understanding on power and politics is expressed as fifth step to enhance social work ethics education. The main discussion point of social work ethics is shaped as to individual differences so, social workers must study on the intervention plan like composing a song as to autonomy of the clients and also inform their clients in every stage of the plan.

\section{Informed Consent}

In a professional practice, clear and comprehensible informing an obligation as a part of evidence-based practice as well as willingness of client. A client can participate in social work practice voluntarily as much as openness of problems, needs and interventions have occurred. In that way, social work education has a responsibility to the clientsregarding informed consent that possesses a role to gain client's voluntary agreement to social worker and client interaction within social work intervention (Burkemper, 2004, p. 142).Informed consent, which is required for clinical trials, scientific researches, professional interventions and practices, aims to reflect sufficient information about purpose, benefits, risks and other necessary information of the study or practice to allow participant, patient or client regarding individual self-determination to be volunteer for participation in process. The language is a critical part of informed consent, since it supports to understand by the participant in the way of finding meaning by her/himself (Nijhawan, Janodia, Muddukrishna, Bhat, Bairy, Udupa and Musmade, 2013, p. 134).A well-structured informed consent template should include a rational design in the 
framework of general information about social work intervention, client rights and responsibilities, expertise and knowledge of social worker, professional relationship within the change process, confidentiality and limits of the relationship and intervention, recording and writing process, fees and disclaimer (Burkemper, 2004, p. 145). A discussion issue in the context of social work ethics education as related informed consent can be appeared as that a patient's decisional capacity in the emergency case and participation in medical treatment. This discussion has an important role in two aspects as firstly possessing legal right to reject treatment and autonomy for protecting physical integrity with the perspective of the patient (McCormick et al., 2014, p. 349). In such a case, patients or clients, who have ability for self- expression, thinking and making decision in the sense of mental health as described in criminal law, can prefer the best alternative for her/himself. Otherwise, social worker or practitioner must benefit from the other codes of social work ethics such as helping clients, creating suitable conditions to support personal change and development, respecting the rights and welfare of the clients.

Ethical values have transformed with the development of technology and using in social work interventions to meet needs. While many methods for intervention such as online of telephone counseling, videoconferencing, Web- based intervention, electronic social networks and records help the social worker to enhance the skills, they can new ethical discussions and standards. This view and great influence of technology on social work has forced to elaborate core ethical values and codes. These standards can be included in guideline of NASW, ASWB, CSWE, CSWA Standards for Technology in Social Work Practice as providing information to the public about services and social work topics that using technology, facilitating with technology the delivery of services such as counseling, case management and other social work functions and interventions, gathering, managing and storing information about the clients via electronic records by regarding confidentiality and advocacy, using technological developments in social work education and supervision (https://www.socialworkers.org/LinkClick.aspx?fileticket=lcTcdsHUcng\%3d\&portalid=0).

\section{Anti- Oppression as an Ethical Value in Social Work}

Managing diversity in various fields such as race, disability, sexuality is a raising concept in the context of equal opportunities, awareness to differences and construct social policies. Besides, mainstreaming fosters the reflection of requirements, changes and differences in terms of perception on social reality of individuals that get involved in various groups, orientations and environments (Clifford \& Royce, 2008, p. 6). Moreover, social work 
ethics education focuses on enhancing otherness ${ }^{2}$ of students so that they can find and nourish their own characteristics about intervening in the light of professional knowledge and skills in social work (Tsang, 2017, p. 313).

Social changes and mobility with migration requires social workers to enhance their cultural competencies and understanding of cultural identities in terms of various ethical values as antidiscrimination, anti- oppression, anti- racist views. NASW Standards and Indicators for Cultural Competence in Social Work Practice states ethical responsibilities to culturally different clients as understanding cultural differences in human behavior and social environment, expanding choices and opportunities for oppressed, disadvantaged and exploited people and groups, promoting policies and practices in the light of governmental regulations, human rights, equity and social justice, respecting race, ethnicity, gender identity or expression, age, marital status, political belief, religion, immigration status, mental or physical disability (https://www.socialworkers.org/LinkClick.aspx? fileticket=7dVckZAYUmk\%3d\&portalid=0). Mungai, Wairire, and Rush (2014, p. 174) exemplified the importance of cultural basis of social work regarding ethics education as that many clients can describe their problems such as violence or early marriage as a part of their culture and they highlight their cultural values and norms. In this case, on the one hand, social workers should understand the cultural framework of the problem on the other hand, he/she should try to find legal solution and ways for increasing welfare. Antioppressive social work principles that are significant in social work program qualifications have focused on issues related with social difference, reflexivity, cultural background, interacting social systems, power (Clifford \& Burke, 2005, pp. 683-685).

Sanders and Hoffman (2010, p. 10) contribute to social work ethics education in macro perspective with Bernard Gert's (1998) theory of common morality, which presents an informal public system describing the necessity of moral rules and ideals for shaping human behaviors and supporting continuity of society. While moral judgment expresses the resolving way of an individual for an ethical dilemma, ethical sensitivity means the ability to identify and reframe an ethical issue. Moral judgment and ethical sensitivity appear to be important elements of social work ethics education in order to constitute every phases of professional interaction (Sanders \& Hoffman, 2010, p. 8). Ethics education prepares the students for the professional social work life. The study results of Ulrich et al.

${ }^{2}$ Otherness is identified as considering separated from conceptual categories about clients and not being able to comprehend the clients' needs and necessities with limited classifications (Tsang, 2017, p. 313). 
(2007, p. 1716) contribute to this perspective by correlating social work ethics education and job satisfaction since having knowledge and skills about ethics helps social workers to recognize and express ethical issues clearly.

\section{CONCLUSION}

Globalization and multicultural perspective have altered the use of ethical approaches. Accordingly, social work has a different central point to solve ethical dilemmas. Social work education has many critical differences such as considering on ethics, values, professional identity and human rights in the framework of undergraduate and graduate education (Pawar \& Thomas, 2017, p. 653). Social workers have a professional obligation to be equal, sensitive and understand the differences while handling vulnerable groups(Mungai et al., 2014, p. 171). Social work ethics education has three main element in the way of sharing knowledge with the students as lecturer's own ethical perspective and model to appropriate behavior and thought about the 'appropriate' (Clifford \& Royce, 2008, p. 4).

Codes of ethics should be handled with a broader perspective in all courses of a social work program. Davidson (2005, p. 511) summaries the social work ethics education as identifying boundary violations, developing critical thinking skills and awareness of self and other and initiating prevention policies and strategies. Social work ethics has a twoway role that program curriculum has shaped with broader issues while teaching the students decision making process. Furthermore, social work ethics has a mediator role in the balance with fair, nondiscriminatory, legitimate, social policies and procedures (StromGottfried, 2000, p. 251). In the light of all these discussion topics, it is recommended to consider on new ethical perspectives with changing behaviors, thoughts, feelings and social structures for further studies.

\section{REFERENCES}

Alptekin, K. (2016). Başlangıçtan Bugüne ve Yarına Türkiye'de Sosyal Hizmet Eğitimi. Konya: Atlas Yayınevi.

Biggerstaff, M. A. (2005). Social work ethics online: Reflective learning. Journal of Technology in Human Services, 23(3-4), 245-257.

Bryan, V. (2006). Moving from professionally specific ideals to the common morality. Journal of Teaching in Social Work, 26(3-4), 1-17.

Burkemper, E. M. (2004). Informed consent in social work ethics education. Journal of Teaching in Social Work, 24(1-2), 141-160. 
Clifford, D., \& Burke, B. (2005). Developing anti-oppressive ethics in the new curriculum. Social Work Education, 24(6), 677-692.

Clifford, D., \& Royce, M. (2008). Equality, diversity, ethics and management in social work education. Social Work Education, 27(1), 3-18.

Congress, E. P. (2002). Social Work Ethics for Educators. Journal of Teaching in Social Work, 22(1-2), 151-166.

Davidson, J. C. (2005). Professional relationship boundaries: a social work teaching module. Social Work Education, 24(5), 511-533.

DiFranks, N. N. (2008). Social workers and the NASW code of ethics: Belief, behavior, disjuncture. Social Work 53(2), 167-176.

Dodd, S.-J., \& Jansson, B. (2004). Expanding the boundaries of ethics education: preparing social workers for ethical advocacy in an organizational setting. Journal of Social Work Education, 40(3), 455-465.

Hugman, R. (2005). Exploring the paradox of teaching ethics for social work practice. Social Work Education, 24(5), 535-545.

McCormick, A. J., Stowell-Weiss, P., Carson, J., Tebo, G., Hanson, I., \& Quesada, B. (2014). Continuing education in ethical decision making using case studies from medical social work. Social Work in Health Care, 53(4), 344-363.

Mulé, N. J. (2006). Equity vs. Invisibility: Sexual Orientation Issues in Social Work Ethics and Curricula Standards. Social Work Education, 25(6), 608-622.

Mungai, N. w., Wairire, G. G., \& Rush, E. (2014). The challenges of maintaining social work ethics in Kenya. Ethics and Social Welfare, 8(2), 170-186.

Nijhawan, L. P., Janodia, M. D., Muddukrishna, B. S., Bhat, K. M., Bairy, K. L., Udupa, N., Musmade, P. B. (2013). Informed consent: Issues and challenges. Journal of Pharmaceutical Technology and Research, 4(3), 134-140.

Pawar, M., \& Thomas, M. (2017). Social work education in Australia and the USA: comparative perspectives and contemporary issues. Social Work Education, 36(6), 648-661.

Pugh, G. L. (2017). A model of comparative ethics education for social workers. Journal of Social Work Education, 53(2), 312-326.

Reamer, F. G. (1998). The evolution of social work ethics. Social Work, 43(6), 488-500.

Reamer, F. G. (2013). Social Work Values and Ethics (4th Edition ed.). New York: Columbia University Press.

Reid, P. N., \& Billups, J. O. (1986). Distributional ethics and social work education. Journal of Social Work Education 22(1), 6-17.

Sanders, S., \& Hoffman, K. (2010). Ethics education in social work: comparing outcomes of graduate social work students. Journal of Social Work Education, 46(1), 7-22.

Strom-Gottfried, K. (2000). Ethical vulnerability in social work education. Journal of Social Work Education, 36(2), 241-252.

Tsang, N. M. (2017). Otherness and empathy-implications of Lévinas ethics for social work education. Social Work Education, 36(3), 312-322.

Ulrich, C., O’Donnell, P., Taylor, C., Farrar, A., Danis, M., \& Grady, C. (2007). Ethical climate, ethics stress, and the job satisfaction of nurses and social workers in the United States. Social Science \& Medicine 65, 1708-1719. 